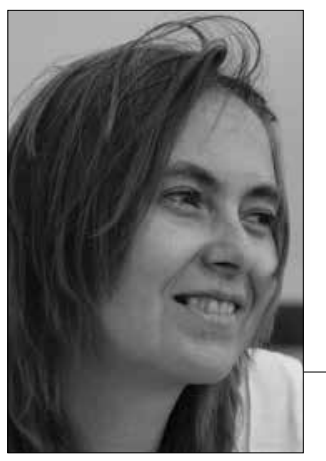

\section{SALOMĖJA JASTRUMSKYTE்}

Lietuvos kultūros tyrimų institutas, Lietuva

Lithuanian Culture Research Institute, Lithuania

\title{
SINESTEZIJOS ESTETIKOS PRIELAIDOS IR SAMPRATA
}

\section{The Aesthetics of Synaesthesia: Conception and Assumptions}

\begin{abstract}
SUMMARY
The aesthetics of synaesthesia, first of all, is the compilation of diverse, mostly non-historical vectors with sensory interactions, which permeate the human-made culture. In traditional aesthetics of the 19th-20th centuries, these vectore are most recognised on the plane of interactions between art and the different types of art. Over time, however, it has been discovered that they cover all embedded, conscious or non-articulated vital human activities, which unfold sensorially in the conditions of the megasocium, which has no historical analogues. The aesthetics of synaesthesia also includes multifaceted and not necessarily homogeneous manifestations, integrated and interacting in a sensual human plane. In the traditional aesthetic thought, which prevailed almost until the end of 20th century, the interpretations of the synaesthesia phenomenon were mainly concerned with programmed cases of interaction between different arts. This was an attempt to predispose and limit synaesthesia in the Western aesthetic tradition as yet another, even though a controversial, aspect. In the 21 st century, with the growth of synaesthesia research, the synaesthesia situation became questionable and the aesthetic articulation of synaesthesia moved beyond the boundaries of art to encompass all human activity in the living world. Moreover, the aesthetics of synaesthesia covered the selfperception of the personality. It recognised the interactions of multilayered senses in a natural and legitimate way of experiencing the world, which primarily has aesthetic value for an individual
\end{abstract}

\section{SANTRAUKA}

Sinestezijos estetika - tai pirmiausia daugybiški, didžiąja dalimi neistoriški, juslių sąveikų vektoriai, persmelkiantys žmogaus kuriamą kultūrą. XIX-XX a. tradicinèje estetikoje jie dažniausiai atpažistami meno ir skirtingų meno rūšių sąveikos plotmèje, bet ilgainiui atrandama, jog jie aprėpia visą ikūnytą, issisąmonintą arba neartikuliuotą gyvybinę žmonių veiklą, kuri skleidžiasi jusliškai (sensorially) komunikuojant istorinių analogų neturinčiomis megasociumo sąlygomis. Sinestezijos estetika taip pat apima įvairialypes, nebūtinai 
homogeniškas, integruotos ir sąveikaujančios juslinės žmogaus plotmės apraiškas. Tradicinėse, beveik iki $\mathrm{XX}$ a. pabaigos viešpatavusiose estetinejje mintyje sinestezijos fenomeno interpretacijose daugiausia buvo aptarinejjami programiniai skirtingų menų sąveikos atvejai. Tai buvo mėginimas sinesteziją palenkti ir apriboti Vakarų estetikos tradicijoje kaip jos dar vieną, tegul ir prieštaringą, aspektą. Tačiau XXI a. išaugus sinestezijos tyrimų masyvui, tokia sinestezijos padètis tapo kvestionuotina, o sinestezijos estetinis artikuliavimas ne tik pasislinko už meno ribų, apimdamas visą žmogaus veiklą gyvenamame pasaulyje. Maža to, sinestezijos estetika apėmė pačią žmogaus savivoką, pripažindama daugiasluoksnes juslių sąveikas natūraliu ir legitimiu pasaulio patyrimo būdu, kuris individui visų pirma turi estetinę vertę.

S inestezijos estetika - tai daugialypiai, daugiausia neistoriški, juslių sąveiku vektoriai, spontaniškai persmelkiantys žmogaus kuriamą kultūros vertybių ir simbolių pasauli, ypač meninę jo plotmę, taip pat visą ikūnyta issisąmonintą arba neartikuliuotą jusliškai ittarpintą gyvybinę ir kūrybinę žmogaus veiklą. Šios estetikos materialusis pagrindas yra žmogaus juslès, suvokiamos ne tik kaip empirinio patyrimo laidininkas, bet ir kaip plastiškas, universalus ir grindžiantis žmogaus estetinès būties ir meninès saviraiškos formas kūrybinis pradas. Meninè veikla, kitaip nei filosofinis mąstymas, nuo pat savo užuomazgu plačiai rèmėsi kūnu kaip savo instrumentu ir meninės kūrybos proceso medžiaga, o îkūnytos juslès savo veikimu atspindi žmogaus gyvybini ir kūrybini aktyvumą, kuriam daro ittaką ivvairiausi kultūros veiksniai. Visų minètų veiksnių jungtis yra sinestezijos estetikos pamatinès prielaidos.

Sinestezija Vakarų klasikinès estetikos tradicijoje paprastai apibrèžiama kaip graikiškos kilmès sąvokų (syn „kartu“ ir aisthesis - ,suvokti“) vedinys syn-aisthesia, šitaip nubrèžiant esmini sinestezijos sąvokos kontūra, išreiškiantị temporaliai vėlesni atskirų juslių jungima, o ne pirmapradę juslių vienovę. Sąvokos sinestezija graikiškosios šaknys iš esmès nurodo ne individualų juslini patyrima, bet daugiau socialinį reiškinį - veiksmažodis sunaisthanomai ir daiktavardis sunaesthesis, vartoti pirmiausia Aristotelio, žymèjo daugybès individu patiriamą tą pati reiškini arba jutimu darini, kuris steigia gyvos būtybès susidūrimą su pasauliu arba pačiu savimi (Butler, Purves 2013: 1).

Greta tradicinės abstrakčios, etimologine struktūra gristos sinestezijos sampratos, dabartinejje postmodernioje estetikoje vis tvirtesnes pozicijas igauna ìvairūs normatyviniai îkūnytosios ir/ar ¡ikultūrintosios sinestezijos apibrèžimai. Jie dažniausiai kol kas yra dar partikuliarūs, besiremią vienu ar kitu sinestezijos atveju ar aspektu, tačiau jau sutartinai byloja ją esant igimta, reta, savaiminę, automatišką ir kt. būklę. Šios ir panašios sampratos nurodo kūną kaip sinestezijos fenomeno pamata, o kultūrą traktuoja kaip begalinę jos raiškos aibę.

Kita vertus, sinestezija paprastai nusakoma kaip juslių sąveika (tačiau ne vienovè) sensorinio patyrimo akte, arba kaip vienos juslès modalumo perkèlimas ì kitos juslès modalumą. Vèlgi čia atsekame tradicinei vakarietiškai sinestezijos sampratai būdingą mechaniškumą, artefaktiškumą. Vadinasi, ne sinestezijos raiškos meno kūriniuose dažnumas nulemia sinestezijos estetikos pobūdì, artimą ivvairių menu sąveikoms kaip tradicinès estetikos teorinių konstruktų plètiniui. Priešingai, šitaip greičiau iš anks- 
to suponuojama sinestezijos racionali mechaniška sandara, kuri paverčia ją tinkamą tik artefaktams, o ne pilnatviškai sensorinei estetinio patyrimo sklaidai. Todèl daugybe atvejų sinestezija tradicinejje estetikoje yra tiesiog paviršutiniškai sutapatinama su menų sąveikomis ir meno plotme neizžvelgiant, jog tai tèra tik viena iš juslinès ir estetinès žmogaus raiškos teritoriju, kurią gali apimti ir dengti sinestezija.

Toki sinestezijos universalumą jau randame fenomenologinèse Maurice'o Merleau-Ponty ovacijose sinesteziniam patyrimui, kuris yra aiškinamas kaip vis$k a$ apimantis ir natūralus. Galima teigti ir dar paprasčiau: sinestezinis patyrimas tiesiog yra estetinis patyrimas par exellen$c e$, jei pripažistame, kad estetini patyrimą privalo sudaryti nedalomas jusliu visetas.

Sinestezijos apibrèžimai, nors jų gausu ir jie varijuoja, iš esmès sukasi apie tą pačią misslingają juslių mechanika, leidžiančią vienas aktyvuotas jusles versti kitų atsaku. „Sinestezija yra fenomenas, kuriame vienos juslès modalumo stimuliavimas sukelia jutimus kitos juslès modalume", - teigia Crétien van Campen ir Clara Froger (Campen, Froger 2003: 291). Arba: „Sąvoka sinestezija nurodo jutimų jungima, kylanti iš skirtingu juslinių domenü“, - teigia Reuven Tsur (Tsur 2007: 30).

Vadinasi, sinestezija, norint prisikasti prie jos giliausios esmès, pirmiausia reikètų mąstyti ir tirti kaip viena iš galimu Vakaru pasaulio sensoriniu ir estetiniu paradigmu. Tikroveje nepaprastai sudètingo ir daugiasluoksnio sinestezijos fenomeno nekritiškas sureikšminimas, redukuojant ją vien i programines menu sqveikas ar, kitais žodžiais tariant, sintezes, buvo būdingas daugeliui ittakingiausių XIX-XX a. meno ir jo teorijos raiškų, iš tiesų yra romantizmo bei iš jo kylančių ivairiu neoromantiniu estetinių teorijų, ypač simbolizmo estetikos, paveldas. Vakaru estetikos ir meno teorijos tradicijoje sinestezijos sąvoka nurodo ši reiškini esant savotišką dirbtinị sutelktinį darinị, be igimtos pirmapradès, ìkūnytos būties. Tokia sąvokos struktūra tampa lemtinga visai Vakaru sinestezijos tradicijos sklaidai ir iš jos išaugančiai universaliai sinestezijos estetikai.

Iš tikrųju ìvairios sinestezijos apraiškos aptinkamos daugelyje romantinès ir poromantinès epochos kultūros ir meno reiškinių, ypač besiskleidžiančiu poetinès, muzikinès ir dailès kūrybinès raiškos sandūroje. Neatsitiktinai aptariamu laikotarpiu plačiai išplitus sinestezijos meno praktikai, nuo XIX a. pabaigos per visą $X X$ a. sinestezijos tyrimai intensyvèjo įvairiausiose mokslinio pažinimo srityse (estetika, meno filosofija, meno psichologija, literatūrologija, psichologija, neurofiziologija, juslių kultūrologija, juslių antropologija, juslių archeologija ir kt.)

Pastarajị dešimtmeti išryškèjo naujos sinestezijos fenomeno pažinimo tendencijos: prasidejo kryptingas anksčiau viešpatavusių teorijų ir apskritai ligšiolinių sinestezijos tyrimų kritinis sumavimas ir méginimas konceptualiai apibendrinti šioje srityje pasiektus laimejjimus ir nesèkmes. Šias radikalias teorinès minties slinktis akivaizdžiai rodo kokybiškai nauji, pirmą kartą istorijoje išleisti sinestezijos reiškiniui tyrinèti skirti etapiniai, tarsi sumuojantys ankstesnio mokslo laimèjimus, programiniai veikalai, kaip antai sinestezijos enciklopedija, parengta ir išleista Oksforde prieš šešerius me- 
tus: Julia Simner, Edward M. Hubbard (ed.), Oxford Handbook of Synesthesia, Oxford: Oxford University Press, 2013. Iš kitų reikšmingiausių leidinių derètų paminèti: John E. Harrison, Simon Baron-Cohen (ed.), Synaesthesia: Classic and Contemporary Readings, Wiley, 1997; Ophelia Deroy, Sensory Blending: On Synaesthesia and Related Phenomena, Oxford: Oxford University Press, 2017; María José de Córdoba, Dina Riccò, Sean A Day (ed.), Synaesthesia: Theoretical, artistic and scientific foundations, Fundación Internacional artecittà, 2014; Aleksandra Maria Rogiwska, Synaesthesia and Individual Differences, Cambridge: Cambridge University Press, 2015, ir kt.

Itakingas teoretikas Jonathanas Cohenas, apibendrindamas keleto pastarųjų dešimtmečių sinestezijos tyrinèjimuose išryškëjusius poslinkius, taikliai pažymi, jog nepaisant neabejotinu laimèjimų, šis reiškinys vis dar yra mįslingas: „tai, kas yra sinestezija, žinoma menkai arba nieko nežinoma“. Tačiau net tokioje miglotoje dabartinès sinestezijos estetikos raidos paradigmoje neabejotinai imanomos įvairios tolesnès produktyvios plètotès kryptys. Neatsitiktinai vieni autoriai, mègindami pašalinti minètus neaiškumus, èmèsi sinestezijos apibrèžimų ir jų klasifikaciju, kiti - jos formų ivvairovès, sinestezijos kaip psichologinès prigimties reiškinio, igimtumo ar igytumo klausimo ir kt. (Cohen 2017: 60).

Kitas vienas ịtakingiausių dabartinès pragmatistinès estetikos atstovų Richardas Shustermanas atkreipia dèmesi i somaestetika, galimą kurti kaip Aleksanderio Gottliebo Baumgarteno Aesthetica (1850/1758) tęsini (Shusterman 2000: 263-264). Šitaip pajudina juslių sąveikos, sinestezijos estetiškumo pradmenis pa- čiame kūne, o ne už jo esančiame mene. Sinestezijos estetika, jo isitikinimu, privalo daugiau aprèpti daugialypes jusliu sąveikas ir jų estetines vertes nepriklausomai nuo jų raiškos lauko. Iš čia kyla supratimas, kad sinestezijos estetika nèra vien meno kaip tokio ar meno šakų sąveikų estetika. Apribota vien menų sąveikomis, sinestezijos estetika išlieka kaip tradicinès, juslių daugialypiškumą represuojančios estetikos replika, negebanti užčiuopti ir panaudoti pačių esmingiausių estetikos mokslo atveriamu prielaidų.

Sinestezijos reiškinys Vakarų civilizacijose dažniausiai buvo pastebimas tik estetinès ir meninès kūrybos plotmèje. Rytų civilizacijoje, beje, sinestezija (kaip ji suprantama Rytuose) apemè kur kas daugiau kultūrinių, ypač su estetinio suvokimo, meno psichologijos, jautriausių emocinių išgyvenimų sfera susijusių, plotmių. Šie sinestezijos teorijos ir meno praktikos aspektai buvo labai svarbūs indų tradicinejje estetikoje ir atsispindejo ne tik Upanišadose, bet netgi garsiojo mūsų eros pradžioje pasirodžiusio estetikos traktato „Natyašastra“ pamatinejje „,rasa" kategorijoje, kuri turèjo sinestezijos fenomenui labai svarbias "gyvybès sulčiuc", "skonio", "uoslès", "estetinio išgyvenimo", ,estetinès nuotaikos", ,estetinio malonumo" ir kitas semantines prasmes. Upanišadų ir "Natjašastros" nubrèžtas sinestezijos fenomenų tyrinèjimo laukas savitai atsiskleidè alankarikų ir ypač stiprios tantrizmo itakos pažymėtų Kašmyro mokyklos žymiausių atstovu Anandavardhanos ir Abhinavaguptos koncepcijose.

Ne mažiau dėmesio sinestezijos problematikai buvo skiriamas ir Rytų Azijos kinų (daoistinėse, čanbudistinèse, tan- 
tristinėse) ir ypač japonų (šintoistinėse, dzenbudistinèse, tantristinèse) estetikos ir meno teorijose, kurios itin daug dèmesio visada skyrè psichologiniams menu sąveikos aspektams. Tai lèmè ir japonų estetikos pamatinèse kategorijose atsispindejusi ypatingą dèmesi meno psichologijos problematikai. Daug panašiu dalykų galime surasti arabų musulmoniškame pasaulyje didžiulę ìtaką igavusioje sufijų estetikoje. Tačiau sinestezijos problematikos sklaida Rytų tautų estetinès minties raidoje yra atskiras sudètingas problemų laukas, kuris reikalingas savarankiškų išsamių tyrinejjimų, todèl ji dabar sąmoningai paliekame už mūsų tyrimo ribų ir grižtame prie Vakarų estetinès minties tyrinèjimo.

Pagrindinè sinestezijos raiškos sritis Vakaruose buvo įvairių meno rūšių, pirmiausia tapybos ir muzikos bei poezijos ir muzikos, sąveikos probleminis laukas, kuris tiesiogiai siejosi su ivvairiomis psichofiziologinèmis žmogaus kūno reakcijomis. Turëjo būti nueitas ilgas dvieju šimtmečių kelias, kol sinesteziją imta suvokti ne kaip meno plotmejje užgimstančia, bet kaip pastarąją savaime aplankančią arba joje sąmoningai naudojamą, priklausomai nuo atitinkamo laikotarpio pasaulěžiūros ir estetinių nuostatų. Sinestezijos tyrimuose pastebimi du pakilimo laikotarpiai. Tai XIX a. priešpaskutinieji du dešimtmečiai: ,begining in the 1870s, the number of published studies about synasthesia grew tenfold, reaching its peak in the decade of the 1890s." (Harrison 2001: 27) ir XX a. pabaigos du dešimtmečiai. XIX a. pabaigos sinestezijos samprata akcentavo abstrakčią ir poetišką romantizmo ideologiją, kurioje sinestezija yra tikrasis pirmapradis sensorinis patyrimas, o vadinamasis norma- lus sensorinis patyrimas yra nuopuolio būklè (Betancourt 2007: 61), XX a. pabaigos sinestezijos tyrimai siekė mokslinio objektyvumo ir pabrèžè sinestezijos ik $\bar{u}$ nytumą ir sensorinį alternatyvumą. XIX a. požiūris atvedè i modernizmo eksploatuotus programinius sinestezijos modelius, o XX a. pabaigoje suformuotas sinestezijos îkūnytumo modelis nubrèžè sinestezijos socialumo, globalumo, bendražmogiškumo trajektorijas suponuodamas savotišką sinestezinę epistemologiją. Iš pastarosios kyla vis nauji sinestezijos artikuliavimo ir itarpinimo kultūroje pavidalai.

Reikia pasakyti, jog XXI a. pirmieji du dešimtmečiai nebeakcentuoja sinestezijos kaip subordinuotos meno sričiai, - suaktualëjęs antropologinis atskaitos taškas keičia ir sinestezijos estetikos aši. Dabar sinestezijos estetika dažniausiai suvokiama kaip universali žmogaus juslyno duotis, galinti pasireikšti bet kokioje kultūrinèje plotmejje. Svarbu ir nuostabu tai, kad būtent pats sinestezinis ivvykis sudaro pati estetinio suvokimo akta, t. y. sinestezinis patyrimas iš esmès sutampa su estetiniu, telieka pasitelkus filosofinę estetiką artikuliuoti šią sutaptį.

Be to, dera paminèti, jog Rytų kultūrose sinestezija nebuvo atplèšta nuo estetikos, tad šie rekonstrukciniai procesai būdingi labiau Vakarų sinestezijos sampratai. Jie pasirodo net tada, kai Vakaru mokslininkai ima tirti sinestezijos atvejus Rytų kultūros dariniuose, pavyzdžiui, indu, kinu, naudodamiesi vakarietiškaja sinestezijos sampratos mechanika ir jos nekvestionuodami (Sanford, W., A. 2009; Hung 2011) Mechaninis sinestezijos modelis, ì Vakarų estetiką atèjęs ir per sudurtinę graikiškų žodžių sąvokos prigimti, palikusią dinamišką sąnari tarp 
jungiamu dalių, ir Bertrand'o Castelio clavesin oculaire mąstymo esksperimenta, visa savo esme priklausiusi Apšvietos mechaninei vaizduotei, yra Vakaru sinestezijos ir jos estetikos bruožas. Tad ir sinestezijos pirminis įtarpinimas meninëje, artefaktinèje terpëje yra šio mechanicizmo implikacija.

Kaip matysime vèliau, Baumgarteno kurta estetikos sritis filosofijoje taip pat buvo sukaustyta Apšvietos mechanikos, apgaubusios visą kultūrini lauką tikèjimu konstravimo galia, lygiai kaip Romantizmas šią mechaninę proto galią pakeis vèl viską apimančiu tikèjimu dvasiniu tolydumu. Baumgarteno veikale yra akivaizdžios prielaidos suvokti estetiką kaip nedalomą savaimini vyksmą, iškylanti iš žmogaus juslinio tolydumo. Tuo šios prielaidos pasirodo esančios artimos XX a. pabaigoje susiformuosiančiai savaiminès, nevalingos sinestestezijos sampratai, tačiau XVIII a. priimtini mąstymo modeliai paslepia tokias mąstytojo ižvelgtas estetikos ištakas. Jo estetikos pamatinè sutelktis buvo pojūtis ir iš jo kildinamas estetinis patyrimas. XVIII a. filosofijos masyvui sąvoka "pojūtis" apskritai buvo svetimkūnis, ir šią padèti Baumgartenas gelbsti estetikai suteikdamas žemesni statusą nei gnoseologijai.

İdomu tai, kad 2013 m. Oksforde išleistoje Oxford Handbook of Synesthesia yra atskiras skyrius pavadinimu "What exactly is a sense" (Keeley 2013: 941959). Taigi pamatinis dalykas, igalinantis XVIII a. estetikos kaip savarankiškos filosofijos šakos ir XX-XXI a. sinestezijos kaip savarankiško ir milžiniško mokslinio objekto sajunga, yra pojūtis. Būtent pojūtis kaip toks liko Vakarų estetikos ir meno paraštėse, neapmąstytas, nesutelktas, atsitiktinis ir tarsi nebūtinas egzista- vimui to, kas iš tiesų tik dẻl jo ir gyvuoja. Kūno ir proto santykiu problemoms Vakaru mąstymo tradicija paskyrè ne vieną tūkstanti puslapiư, bet pojūčiu ir kūno santykis kaip toks estetikoje nebuvo įžvelgtas.

Juslių ir jų aktyvumo pagrindo, kūno, santykis ilgą laiką nebuvo kruopščiai artikuliuotas. Šito trūksta ir šiandien, net esant gana didelei sinestezijos tyrimu apimčiai. Juslėmis, pojūčiais ìvairiu pakraipu tyrinėjimuose ir menineje praktikoje bei filosofinès estetikos spekuliacijose dažniausiai buvo operuojama kaip autonomiškais dariniais, tarsi jie būtụ atsieti nuo kūno, iškūnyti, abstraktūs ar simboliški, veikiantys kaip atskiri, nepriklausomi elementai, iš kuriu konstruojami ypatingi kultūriniai, estetiniai, meniniai pavidalai, t. y. įsivaizduojamas, metaforiškai kalbant, savotiškas „pojūčiu skliautas", kuriame gali skleistis sinestezijos ivvykiai. Būtent šis abstrahuotas, racionalizuotas pojūčiu savarankiškumas buvo ir yra vienas esminių Vakarų sinestezijos fenomeno ir jo itakos paveiktos estetikos bruožų.

Ši pamatinè diskrečių ir autonomišku jusliu prielaida sinestezijos estetinèje sampratoje dar nèra deramai ižzelgta ir apmąstyta. Skverbiantis ì ši problemu lauką iškyla daugiau klausimų nei aiškiai artikuliuotų atsakymų. Tai, ką galètume vadinti sinestezijos estetika, daugiausia buvo meninès programos, skelbiančios pojūčių vienovę tarnausiant vieniems ar kitiems estetiniams, netgi etiniams tikslams, tačiau beveik visiškai nenurodant jos sensorial egzistavimo ir veikimo pamato, principu, sąlygų.

Galima teigti, jog be sinestezijos teorinès recepcijos, modernios vakarietiškos estetikos mozaika būtų neišsami, nevien- 
tisa ir jos kuriami vaizdiniai liktu neatpažistami. Beje, sinestezijos iškilimas Vakarų kultūroje sutampa su reprezentacijos krizès pradžia, arba, kitaip pasukus šio įvykio reikšmès briauna, susilieja su reprezentacijos krizès reiškiniais bei problemomis, atspindi jas ir pateikia galimas jų sprendimo alternatyvas. Iš to išplaukia, kad sinestezija sugrižta i Vakarų estetikos ir meno sceną tada, kai pastaruju galios jau išsisėmusios ir susikompromitavusios. Naujų meno idealų ir kūrybinès saviraiškos formų suintensyvejjusi spontaniška paieška pagrindiniuose meninès kultūros centruose tada stiprių dramų ir lūžių krečiamai XIXXX a. sandūros Vakarų kultūrai atveria naujas menų sąveikos galimybes. Todèl tuometinė gimstančio modernistinio meno panorama kaip niekuomet anksčiau tirštai nusėta sinestezijos proveržiais. Vadinasi, sinestezija negalejjo būti tik periferinis kompensacijos atvejis silpstančiai senajai Vakarų estetinei ir meno tradicijai (tokių kompensacijos galimybiu buvo daug ir ivairiu), bet jis apnuogino tradicinès estetikos konstrukcijose buvus pernelyg iškreiptą ir suvaržyta, represuotą pojūčių struktūrą.

Kadangi XIX-XX a. audringiausios meninès ir estetinės kaitos dešimtmečiai yra susiję su įvairių represinių mechanizmų atpalaidavimu (vienas ryškiausių pavyzdžių yra psichoanalizès atsiradimas, kilęs iš pamatinių Vakarų mąstymo tradicijos postūmių pasąmonès struktūrų link, libido simboliu ženklintos fiziologinès žmogiškosios egzistencijos prigimties suvokimo), sinestezijos reikšmès iškilimas taip pat gali būti vertinamas kaip viena iš žmogiškosios sensorinès būties išsilaisvinimo formų. Šis pojūčių išlaisvinimas prasideda jau nuo XVIII a. vidurio, o sulig modernistinio meno ir estetikos kulminacija regime ir juslinès patirties isiaudrinima, kraštutinius jos igyvendinimo pavidalus. Kaip šio igyvendinimo viršūnè nuolat iš kultūrinès pasąmonès gelmių îvairiais pavidalais išnyra sinestezija. Sinesteziškumas tampa aukščiausia estetine kategorija romantizmo ir simbolizmo epochose, o modernizmo epochoje netgi skelbiamas kaip naują dinamiškos epochos dvasią atitinkanti estetikos pakopa, kurioje igyvendinami aukščiausi žmogaus estetiniai, meniniai polèkiai ir reikmès. Ir nors dar nèra suvokiama, jog ši romantinè, simbolistinè ir modernistinè sinestezijos apoteozè yra Apšvietos mechanicizmo tęsinys estetikoje, mene, filosofijoje ir netgi ikūnytumo pažinime, ją derètų priimti tik kaip vieną iš sinestezijos ir jos estetikos kristalizavimosi etapų.

Dar nè vienas žmogui būdingas fenomenas nesukèlè tokio milžiniško ir nuolat augančio susidomėjimo kaip sinestezija, kuri, anot Julijos Simner ir Edwardo M. Hubbardo, parodo neittikètiną daly$\mathrm{ka}$ - ne visų individų pasaulio suvokimas yra vienodas (Simner, Hubbard 2013: xx). Tokio fakto konstatavimas sukrečia esminius žmogaus savivokos pamatus, radikaliai pajudina vadinamąją ,kitų sąmonès problemą", kai veikdami ir komunikuodami pasaulyje vadovaujamės nuostata, jog kiti asmenys suvokia realuji pasauli daugiau mažiau vienodai, ir tai leidžia koordinuoti veiksmus. Tačiau sinestezija jau nuo pirmųju istoriniu jos empiriškai fiksuotų atveju, kaip antai Georgo Tobias'o Ludwigo Sachso 1812 m., pasirodè esanti uždara ir imanentiška tiek, jog negalima jos nei atspèti, nei iškoduoti, nei juolab iškomunikuoti. Net stebina, kodèl taip ilgai sinestezija, būdama už- 
dara komunikavimui, dar neatradus jokių elementarių jos konstantų, galejjo būti tokia geidžiama ir šitaip plačiai eksploatuojama Vakarų mene.

Vèl čia galime užčiuopti XVIII a. racionalizmo prada, mechaniškai pajungianti visus įmanomus elementus procesams ir dariniams, nesigilinant i juc neartikuliuotaji individualuma, kuris veikiausiai yra Rytu sinestezijos sampratos esmė (japonų kalboje nėra net sąvokos, atitinkančios Vakarų sinestezijos sąvoką). Neartikuliuotasis, netiesinis individualumas sinestezijoje, lygiai kaip ir estetikoje, buvo suvoktas ir pripažintas tik XXI a. susidūrus su dinamiško, junglaus, tolydaus, komunikuojančio megasociumo struktūra ir masyvu, kai vargu ar dar gali veikti siaurai suprastas Apšvietos racionalizmas. Juo didesnè visuomenè, juo ji iracionalesnè, juo labiau joje atsiskleidžia netiesiniai žmogaus prigimties bruožai.

Neatsitiktinai sinestezijos stipriausios ir ryškiausios perspektyvos XXI a. trečiajam dešimtmečiui numatomos būtent sociokultūrinèje, socioantropologinèje terpejje (Howes, Classen 2013), priimant ir tai, jog meno plotme taip pat tapo nestruktūruota megaterpe estetinei percepcijai. Taigi galime daryti prielaida, jog sinestezijos estetika yra savita parengtis suvokti meninius darinius, kurie visiškai nauji tiek savo prigimtimi, tiek valdomais kontekstais. Sinestezijos estetika jokiu būdu nebegali likti siaura, spekuliatyvia, meninius lokalius reiškinius aprūpinančia estetika. Tokia ji (nors su išlygomis) dar galëjo išlikti XIX-XX a., tačiau keista jos ekspansija pastarajame šimtmetyje rodo visai ką kita.

Milžiniškos komunikuojančios žmonių populiacijos, neegzistavusios iki šiol, kitaip pakreipia žmogiškojo juslyno eksploatavimą - taip pat ir estetiniu aspektu. Be to, moksliniai tyrimai atskleidžia ir tai, jog būtent per didelius populiacijos mastus sinchronizuojasi sinestezijos konstantos, aptinkama vis daugiau individų, juslių sąveikas (šiuo metu yra nustatyta 150 pasireiškiančių populiacijoje sinestezinių derinių) suvokiančių daugiau ar mažiau identiškai. Todèl žvelgdami i meno ir estetikos perspektyvas XXI a. būsimais dešimtmečiais, sinestezijos estetikos negalime uždaryti kaip inertiško ir retrospektyvaus reiškinio. Tai, kaip sinestezija dalyvavo ar dominavo XIX ar XX a. estetikos terpeje, vis ryškiau skiriasi nuo to, kaip ji pasirodo XXI a. juslinèje žmogaus veikloje. Vienas ryškiausių sinestezijos integravimosi Vakarų kultūroje bruožų yra tas, jog ilgainiui ji vis labiau susilieja ir tampa tapati estetiniam patyrimui, o tiksliau, šiuo procesu sugrižta represuotas ir suardytas Vakarų estetikos tolydumas.

Sinestezija nesutampa su pasyviu, nesuinteresuotu estetinio stebejjimo aktu, nuodugniai išskleistu vokiečių idealistinèje estetikoje, visu pirma Immanuelio Kanto darbuose. Sinestezija gretinasi prie vadinamosios neklasikinès estetikos, meno filosofijos (Arthuras Schopenhaueris, Sørenas Kierkegaard'as, Friedrichas Nietzsche, Henri Bergsonas), atpalaiduojančios iracionalios valios stichijai pavaldžias žmogiškojo patyrimo, intuicijos, spontaniškų kūrybinès dvasios polèkių gyvybines galias ir išaukštinančios atskiro individo egzistencinę patirti. Tai patvirtina ir faktas, jog jau XIX a. viduryje, atitinkamai romantizmo idealams, tapo suvokta ir pripažinta, kad sinestezija yra itin individuali, autentiška ir nepakarto- 
jama, net ir nekomunikuojama pabrèžtinai subjektyvios prigimties patirtis.

Nors romantizmo menininkus dar masino sinestezijos elitinis, subjektyvistinis ir solipsistinis modelis, jau simbolizmas sinestezijai suteikè skelbiamos naujos žinios, kvietimo, pažado pavidala kuris, beje, yra ypatingo romantinio elitarinio sinestezijos modelio įsitvirtinimo pradžia. Šis modelis iki šių dienu sinesteziniam patyrimui rezervuoja išrinktumo, unikalumo, net socialinès atskirties poziciją. Reikia pažymèti, kad sinestezijos elitiškumas yra vienas ryškiausiu bruožų, skiriantis romantizmo, ir ypač simbolizmo bei iš dalies modernizmo, sinestezijos estetiką ir vertas atskiro teorinio demesio.

Sinestezijos estetikos aktualumas taip pat glaudžiai siejasi su individo sampratos kaita. Sinestezijos fenomenas galëjo igauti svarbu vaidmeni tik susiformavus tam tikroms vidinès žmogaus patirties, jo jausmu, išgyvenimu, pojūčiu sampratoms. Diskutuotina, kiek šios naujos sampratos igavo galios visuomenèje, kiek jos tapo plačiai priimtinos, visuotinès ir jaudinančios. Tad sinestezijos aktualumas tam tikru laikotarpiu priklauso nuo dvilypio plano: nuo to, kaip vertinamas asmuo, jo individuali jausminè ir jusliné patirtis, ir nuo to, kiek aiškiai yra susiformavusi pati sinestezijos samprata, kad taptų individualaus suvokimo variaciju pagrindu. Pradedant romantiz$\mathrm{mu}$, šie abu planai pakankamai susiformavo ir ėmè sutapti.

Galime daryti prielaida, jog sinestezija anaiptol nèra paviršutinis estetikos ir meno slinkčiu raibuliavimas, bet priešingai - universalus reiškinys, iš pagrindụ ginčijantis žmogaus pojūčių struktūra, ant kurios rymo daugiau ar mažiau vientisa Vakaru estetika. Todèl sinestezijos teorinių sąvoku, manifestų ir kitų programinių dokumentų tyrinèjimas, ju atranka iš daugybės sinestezijos galimybes pasitelkusių meninių ir kultūriniu reiškinių, atskleistų vieną iš pamatinių aspektu, grindžiančiu Vakarų estetikos ir meno teorijos kontūrus. Sinestezijos reikšmės universalumas, jos apraišku spontaniškumas, estetinis plastiškumas, semantinis talpumas ir kiti erdvūs matmenys néra Vakaru estetikos atsitiktinumas, paklaida ar kompensacija. Visus pojūčius aprépiantis požiūris i meną ilgą laiką buvo svetimas Vakaru estetikai, todèl buvo išstumtas, ir vienas šio tyrimo uždavinių yra būtinybẻ iš esmès ji legitimuoti.

Dera pabrèžti, jog esminio skirtumo šiuolaikineje sinestezijos epistemologijoje tarp Vakaru ir Rytu nèra, universalistinès mokslo tendencijos dažniausiai nebekuria opozicinių struktūru, tačiau esama skirtumu sinestezijos epistemologinèse prielaidose ir ypač sinestezijos estetikoje. Štai įdomi lygiagrete. Iki XXI a. pirmojo dešimtmečio pabaigos turbūt itakingiausia pasaulyje buvo JAV mokslininko, neurologo Richardo Cytowico neurofiziologine sinestezijos paradigma. Sinestezijos tyrinëjimams paskyręs savo gyvenimą šios stulbinamai įtakingos paradigmos kūrèjas nuo $X X$ a. aštuntojo dešimtmečio atgręžè mokslo ir meno žvilgsnius i sinesteziją kaip itin reikšminga, tačiau natūralią žmogaus juslyno savybę. Cytowico teorijos pamatuose idėmesnis žvilgsnis išskiria XIX a. neklasikinès filosofijos (pvz., Arthuro Shopenhauerio), taip pat ankstyvosios pragmatistinès estetikos (Johno Dewey), religijos fenomenologijos, psichodelikos, mistinio patyrimo, dzen meditacijos ir kt. itakas 
(Cytowic 2002). Išskirtinę vietą Cytowico teorijoje užima estetika ir menas, iš esmès visa jo teorija skirta praplèsti, išjudinti inertišką Vakaru estetikos sampratą. Pastaruoju metu, nuo XXI a. antrojo dešimtmečio pradžios, kilusi nauja mokslinio domèjimosi sinestezija banga siejasi ir su kitos išskirtinès asmenybės, indų kilmés mokslininko, taip pat neurologo Vilayanuro Subramaniano Ramachandrano, laikomo žymiausiu šių dienų neuromokslo atstovu, teorija. Nors ši teorija, kitaip nei Cytowico teorija, nèra skirta vien sinestezijos tyrinejjimui, tačiau šiam mislingam jusliniam reiškiniui skiria ypatingą demesị ir atveria sinesteziją milžiniškame šiuolaikinio neuromokslo bei kultūros ir meno kontekste, apimančiame tiek Rytus, tiek ir Vakarus (Ramachandran 2011). Reikia atkreipti demesi i tai, jog Ramachandrano sinestezijos tyrinejjimais ypač siekiama per sinestezijos prizmę peržvelgti visą esamą estetiką ir mena, šitaip įvertinant sinestezijos vietą ir îtaką kasdieniam žmogaus gyvenimui, kasdieniam estetiniam patyrimui.

Sinestezija savo ruožtu skatina dialoga, nes pasirodydama kaip ypatingas reiškinys, ji visų pirma yra savitos, nekompromisinès estetikos skleidèja. Neatsitiktinai sinestezijos meninès apraiškos pasirodè meno istorijos lauke daug anksčiau, nei empiriškai buvo patvirtintas tokio fenomeno buvimas, pirmiau, nei sinestezija buvo itteisinta kaip autentiškas individo patyrimas. Tačiau Douglas Kahnas (Kahn 1999: 120) teigia, jog sinestezines sistemas itteisino būtent tikrų sinestetų ir jų autentiškos patirties buvimas, nepaisant, kiek mažai tai buvo žinoma ir patvirtinta. Didelis menininku susidoméjimas sinestezijos fenomenu
XX a. pradžioje, kai dèl Schopenhauerio ir Nietzsche's muzikos dvasią aukštinančių ideju poveikio skleidèsi daug itakingų modernistinio meno koncepcijų, primygtinai skatino ivvairių sričių mokslininkus peržiūrèti inertiškas sinestezijos sampratas ir mejginti perkelti ją iš patologijos à la mode 1890 m. ar bent kultūrinès marginalijos užribio. Aktualu, jog šis procesas net dabartineje, itin pliuralistinių nuostatų veikiamoje postmoderno kultūroje anaiptol nèra išsisèmęs.

Beje, gausūs šiuolaikinių sinestezijos tyrinèjimų aruodai atskleidžia, jog didelè dalis sinestezinio patyrimo individui turi būtent estetinę vertę (nebūtinai sinestezini patyrimą priimant kaip vieną pagrindinių klasikinès estetikos kategorijų, groži, nors šio požiūrio laikèsi, pavyzdžiui, I. A. Richardsas, Alfredas Northas Whiteheadas). Kitaip tariant, sinestezija papildo, išplečia žmogaus estetinę būtí. Šiuo metu tam pagristi pasitelkiami empiriniai tyrimai, statistika ir pragmatizmo estetika, o menocentrinès, panestetinès epochos, laikiusios meną viena būtiniausių žmogaus būties sričių, sinesteziją įtarpino, steigè meno kūriniuose. Kadangi menas dabar yra praradęs tiek savo esmę, tapatumą (institucinès Georges Dickie, Arthuras Danto ir kt. meno teorijos), kultūrini visuotinumą ir reikšminguma, atskirų meno šakų nuoseklų tęstinumą, kaip tai pabrèžia, pavyzdžiui, plačiai eskaluota tapybos baigtis (kaip tuomet kalbèti apie menu vienovę, iki šių dienų ataidinti romantizmo ir simbolizmo idealą), sinestezijos estetiškumas ar artikuliuota sinestezinè estetika irgi privalejo keltis iš meno ir kolonizuoti kitas kasdienès žmoniškosios būties sritis. 


\section{IŠVADOS}

Glaustai aptarę klasikinès ir naujosios sinestezijos estetikos paradigmines nuostatas ir pastaraisiais dešimtmečiais išryškejusius radikalius teorinius virsmus, galime pereiti prie principinių išvadu formulavimo. Pirmiausia, kaip rodo atliktas tyrimas, sinestezija, nors šiuo metu retrospektyviai atsekama daugybejje skirtingų kontekstų ir šaltinių, Vakarų kultūros, estetinès minties ir meno praktikos tradicijoje visada glūdèjo nuošalyje, kaip neišnaudotų didžių kūrybinės veiklos potenciju kelias. Toks tūnantis latentinis sinestezijos būvis nèra nei atsitiktinis, nei nuosekliai išsirutuliojęs, bet veikiausiai primestas represyvių Vakarų civilizacijos raidos kelyje suformuotų konvencijų.

Antra, sulig Aleksanderio Gottliebo Baumgarteno Aesthetica (1850/1758), nuo jos ir tolyn (vokiečių romantizmas, neoromantizmas, simbolizmas, britų sensualizmo tradicija) estetika, atrasta kaip nauja issisąmoninta ir legitimuota žmogaus patyrimo ir mąstymo sritis, turejo stiebtis kaip ypatinga grynai sensorine ir galiausiai kūno bei intelekto disciplina. Vis dèlto atsiradusi kaip atskiras ir savitas minties laukas racionalizmo, ypač vokiečių klasikinio idealizmo meno filosofijos idejjų klestejjimo amžiuje, ši estetikos mokslo sritis neišvengè tuomet viešpatavusios idejjinès terpès įtakos, kuri tarsi nepastebimai buvo persmelkusi ir užvaldžiusi Baumgarteno ir jo gausių vokiečių sekëjų sinestezijos teorijų konstravimo projektus. Veikiausiai šis racionalizmo persismelkimas estetikos srityje vèliau lèmè jos vis didesnị tolimą nuo neartikuliuojamos juslinès patirties prie dirbtinių struktūru, atstovaujančių protui, bet ne jusliniam patyrimui. Taigi, nors Baumgarteno Aesthetica ir išlieka Vakarų estetikos kilmès riboženkliu (beje, gana simbolišku), jos potencialas ir pirminiai uždaviniai po įtaigių ir menininkų savimeilei pataikaujančiuc neklasikinès ir romantikų meno filosofijos projektų îsigalèjimo buvo beveik užmiršti, o nuosekli joje suformuotų idejjų recepcija nutrūko ir scientistinès, pragmatistinès, neopozityvistinès pakraipos estetikos teorijų buvo iškreipta.

Ir galiausiai, nepaisant daugybès mūsų aptartų idejjinių virsmų, tenka pripažinti, kad sinestezijos estetikos kaip giluminès pojūčių ir kūno disciplinos įtampa išlieka Vakarų meno raidoje ir nuolat prasiveržia savitais vidiniais maištais, tarsi pati estetikos prigimtis nuolat sukiltų prieš jos prisiimtus pančius. Tai vyksta episteminiais lūžiais, nuolat kylančiais ir ypač XX a. tolydžio stiprëjančiais meno savineigos protrūkiais, kaip antai minèta antiesencialistinių meno teoriju problema, atitinkančiais Georgo Hegelio skelbiamos meno pabaigos nuojauta, kuri, nors suvokiama labai natūralistiškai, išreiškia paradoksalų Vakarų estetikos ankštumą ir nepakankamumą.

Taigi jutimiškumas pats savaime Vakarų estetikoje išliko tarsi draudžiamas užribis, naikinantis hejgeliškai taisyklingų jos sistemų soda, pažeidžiantis visuotinę estetikos discipliną. Tai, kad estetikos sklaida rutuliojosi tarsi atsietai nuo pojūčių, naujas susidomėjimas jais lèmė gana groteskišką teorinę padèti, savotišką „pridètinę estetiką", , atskiru pojūčių estetiką", susirūpinusią atskirų pojūtyno darinių reabilitavimu, o tai tarsi nieko bendra neturètų su pačios estetikos esmès igyvendinimu, lyg bendras estetikos masyvas niekada nebūtų iškilęs kaip tik 
dèl pojūtinės veikos apmąstymo. Sinestezijos estetikai toks teorinis nuolydis pavojingas, nes ją taip pat dažniausiai linkstama kurti kaip pridètinę, periferinę, o ne fundamentalia, kritinę estetiką. Todèl kalbèjimas apie juslę, pojūtį estetikoje yra keistai atsargus.

Iš tiesų pojūčio kaip teorinès sklaidos objekto atradimas ir vèliau jo vengimas Vakaru sinestezijos estetikoje rodo anomalią pastarosios būklę. Ar sinestezija galètu išlyginti ši išsikreivinima, jei juo nesuabejojus sinestezijos estetikoje nuolat, tik kitu masteliu, kartojasi pamatinès Vakaru estetikos deformacijos? Tokia sinestezija ir jos estetika lengvai tęstu, tegul ir be galo plèsdama, tradicinės estetikos perspektyvą. Vadinasi, sinestezijos esteti-

\section{Literatūra}

Betancourt M. 2007. A Taxonomy of Abstract Form Using Studies of Synaesthesia and Hallucinations, LEONARDO, Vol. 40, No. 1.

Butler Sh., Purves A. 2013. Introduction: Synaesthesia and the Ancient Senses. Synaesthesia and the Ancient Senses, Shane Butler and Alex Purves (ed.), Durham, Bristol: Acumen.

Campen van C., Froger C. 2003. Personal Profiles of Color Synesthesia: Developing a Testing Method for Artists and Scientists. LEONARDO, Vol. 36, No. 4.

Cohen J. 2017. Synaesthetic Perception as Continuos with Ordinary Perception, or: We're All Synaesthetes Now. Sensory Blending: On Synaesthesia and Related Phenomena, Ophelia Deroy (ed.). Oxford: Oxford University Press.

Cytowic R. E. 2002. Synaesthesia: A Union of the Senses. MIT Press, A Bradford Book.

Harrison J. 2001. Synaesthesia: The Strangest Thing. Oxford University Press, Oxford.

Howes D., Classen C. 2013. Ways of Sensing: Understanding the Senses In Society. London: Routledge.

Hung W. 2011. Investigation Into the Underlying Linguistic Cues of Chinese Synaesthesia, University of Edinburgh. ką kaip radikalią išsekusios klasikinės estetikos priešprieša, reikia diegti apmąstant pojūčiu reikšmę ir padèti, ginčijant ši suvokimą iškreipiančias prielaidas, pripažistant, jog sinestezija yra grynai jutiminis reiškinys, o ne vien tik vaizduotės ir intelekto vedinys. Fundamentalus pojūčuu reabilitavimas teoriniame dabartinès sinestezijos estetikos lauke negrižtamai pakreiptų jos aši, paskatintų rastis naujus meno suvokimo ir analizės metodus, naujus estetinio patyrimo principus ir kurtų naujas sąvokas. Tačiau gali būti ir taip, kad sinestezija su jos estetiniu potencialu bus uždaryta ydingame rate: tam, kad atsirastų nauja sinestezijos grindžiama estetika, reikia pagrịsti sinestezijos buvimą ir būtinumą estetikos ištakose.

Kahn D. 1999. Noise, Water, Meat: A History of Sound in the Arts. Cambridge, Massachusetts, London, England: The MIT Press.

Keeley B. L. 2013. What exactly is a sense. Oxford Handbook of Synesthesia, Simner J., Hubbard E. M. (ed.).

Ramachandran V. S. 2011. The Tell-Tale Brain: Unlocking the Mystery of Human Nature. New York: W. W. Norton \& Company, Inc.

Richards I. A. 1922. The Foundations of Aesthetics. George Allen and Unwin: London.

Sanford W. A. 2009. Singing Krishna: Sound Becomes Sight in Paramanand's Poetry. SUNY Press.

Shusterman R. 2000. Pragmatist Aesthetics: Living Beauty, Rethinking Art. Oxford: Rowman \& Littlefield Publishers, Inc.

Simner, J., Hubbard E. M. 2013. Overview of Terminology and Findings. Oxford Handbook of Synesthesia, Simner J., Hubbard E. M., (ed.).

Tsur R. 2007. Synaesthesia as a Neuropsychological and a Literary Phenomenon. Issues in Literary Synaesthesia, Vol. 41, No. 1, Spring.

Whitehead Alfred North. 1920. The Concept of Nature. London: Cambridge University Press. 